\title{
Customers' Assessment on ATM Services in Bangladesh
}

\author{
Mohammad Shamsus Sadekin ${ }^{1,}$, Md. Abdul Hannan Shaikh ${ }^{2}$ \\ ${ }^{1}$ Department of Humanities, Chittagong University of Engineering \& Technology (CUET), Chittagong, Bangladesh \\ ${ }^{2}$ Department of Management, Islamic University, Kushtia, Bangladesh
}

\section{Email address:}

sadekinmba@yahoo.com (M. S. Sadekin)

${ }^{*}$ Corresponding author

\section{To cite this article:}

Mohammad Shamsus Sadekin, Md. Abdul Hannan Shaikh. Customers' Assessment on ATM Services in Bangladesh. International Journal of Finance and Banking Research. Vol. 3, No. 3, 2017, pp. 39-43. doi: 10.11648/j.ijfbr.20170303.11

Received: May 1, 2017; Accepted: May 17, 2017; Published: June 16, 2017

\begin{abstract}
E-banking implies provision of banking products and services through electronic delivery channels. The study was designed to investigate ATM services in Bangladesh, its impact on social life and security of ATM accounts. The main objective of present study is to find out the practice, impact and security status of ATM booths in Bangladesh. The investigation was concentrated in various divisions, districts and towns in Bangladesh. The sample consisted of 120 bankers and bank customers, were selected purposively from various territory. Out of 120 respondents, 38 bankers and 72 bank customers who use ATM card have given their opinion on many issues of ATM accounts. Data was collected using questionnaire administrated by the researcher. Data were processed through micro computer using Statistical Package for Social Science (SPSS). From the analysis of data the following major findings were obtained i. ATM card holders in Bangladesh feel insecurity from hijacker to withdraw and deposit money from ATM booths and all the ATM booths of Bangladeshi banks are not in safe position.
\end{abstract}

Keywords: E-Banking, ATM, Security, Assessment, Quality

\section{Introduction}

E-Banking, the latest generation of electronic banking transactions, has opened up new window of opportunity to the existing banks and financial institutions. Most of the banks have their own websites but not all of them offer internet facilities. The main reason of this is that the banks do not have the IT infrastructure and proper security features. In Bangladesh most of the people are illiterate and obviously they are technology ignorant [1]. An ATM is simply a data terminal with two input and four output devices. Like any other data terminal, the ATM has to connect to, and communicate through, a host processor. The host processor is analogous to an Internet Service Provider (ISP) in that it is the gateway through which all the various ATM networks become available to the cardholder (the person wanting the cash). ATM has two input devices- card reader and keypad. An ATM has four output devices- Speaker, Display screen, Receipt printer, cash dispenser [2]. Electronic banking does not mean only 24-hours access to cash through an Automated Teller Machine (ATM) or Direct Deposit of pay checks into checking or savings accounts as many consumers may think. Electronic banking (e-banking) involves many different types of transactions; it is a form of banking where funds are transferred through an exchange of electronic signals between financial institution, rather than exchange of cash, cheques or other negotiable instruments [3]. Electronic banking has been around for quite some time in the form of automatic teller machines (ATMs) and telephone transactions [4]. Some of the Foreign Commercial Banks and Private Commercial Banks are already using this optical fiber network for conducting online transactions, ATM and point of sale (POS) services. Bangladesh has joined the information super-highway by connecting itself with international submarine cable system in 2006. A total of 159 Internet Service Providers (ISPs) have now been connected with this system of which 64 are actively providing services. Government to allocate Tk.5, 000 corers to rescue four banks owned by the government [5]. E-Banking is a new concept in banking sector of Bangladesh. It is becoming popular in 
Bangladesh; thus almost all Bangladeshi banks offer many facilities of e-banking. E-banking is growing in Bangladesh day by day. Domestic private commercial banks and foreign commercial banks are in leading position. State owned commercial banks do not offer all the functions of e-banking. Majority of Bangladeshi customers use mobile bank account and ATM account [6]. They were around 50 ATM booths operating in the country; two foreign banks had several ATMs of their own, two local ATM booths service providers that offered syndicated or rental service to several banks [7]. In Bangladesh, credit card and point of sale services (POS) are already provided by a quarter of local banks, while ATM and internet banking were expanding rapidly especially in major cities [7]. A broad spectrum of electronic banking services, a subset of e-finance, is available in Bangladesh with various degree of penetration. Credit card and POS services are provided by $23 \%$ of banks (PCBs and FCBs). Several thousand of POS terminals have been set in major cities of the countries. Tele banking is second most penetrated e-banking service in Bangladesh. ATM is expanding rapidly in major cities. A group of domestic and foreign banks operate shared ATM network, which drastically increase access to this type of electronic banking service [9]. Due to incredible proliferation of Information and communication technology (ICT) the concept of money has been radically changed. Different kinds of business sectors have been merged in a single that can be accessible in a global way and that has been possible just for the proliferation of ICT [10].

\section{Methodology of the Study}

This study has done based on primary data. Data has been collected from 16 selected banks in Bangladesh. Information was collected from the branches of selected banks located in Dhaka, Chittagong, Rajshahi, and Khulna Division. Sample were selected from State Owned commercial banks, domestic private commercial banks and foreign commercial banks in Bangladesh and bank customers were selected from different university, college and school teachers and students, businessmen and other professionals from private and public sectors. Respondents were basically of two categories; bankers and bank customers. Bankers were selected from different branches of selected banks. Two sets of questionnaires were designed and distributed to bankers and bank customers. The questionnaires were distributed directly among the respondents through email. Questions were basically two categories; i. 05 questions are relating to availability and location of ATM account, 08 questions are relating to the security of ATM accounts and ATM booths, 05 questions are relating to the problems and prospects of ATM account and 05 questions are relating to take opinion to solve existing problems of ATM account in Bangladesh. Among the respondents 44 were banker and 76 were bank customers. Data were analyzed by using SPSS software.

\section{Analysis of Data}

Followings are the presentation of the result and analysis of data collected for the study. Responses from total 120 respondents consisting of 44 bankers and 76 bank customers, 98 male and 22 female, 34 married and 86 unmarried, and 28 from rural and 92 from urban areas selected for the study were considered.

Table 1. Various Types of Account are maintained by the Respondents.

\begin{tabular}{llll}
\hline Account & Frequency & Percent & $\begin{array}{l}\text { Cumulative } \\
\text { Percent }\end{array}$ \\
\hline Mobile Banking & 19 & 15.8 & 15.8 \\
Credit Card Account & 6 & 5.0 & 20.8 \\
ATM account & 29 & 24.2 & 45.0 \\
Internet Banking & 13 & 10.8 & 55.8 \\
Debit Card Account & 14 & 11.7 & 67.5 \\
Other & 5 & 4.2 & 71.7 \\
N/A & 34 & 28.3 & 100.0 \\
Total & 120 & 100.0 & \\
\hline
\end{tabular}

Table 1 shows that out of 120 respondents 19 maintains Mobile bank account, 06 has credit card, 43 has debit card (29 ATM card + 14 mentioned Debit card), 13 maintain internet banking, other accounts maintained by 05 respondents and 34 respondents has no on-line account. Some Bangladeshi banks treat ATM card as Debit card.

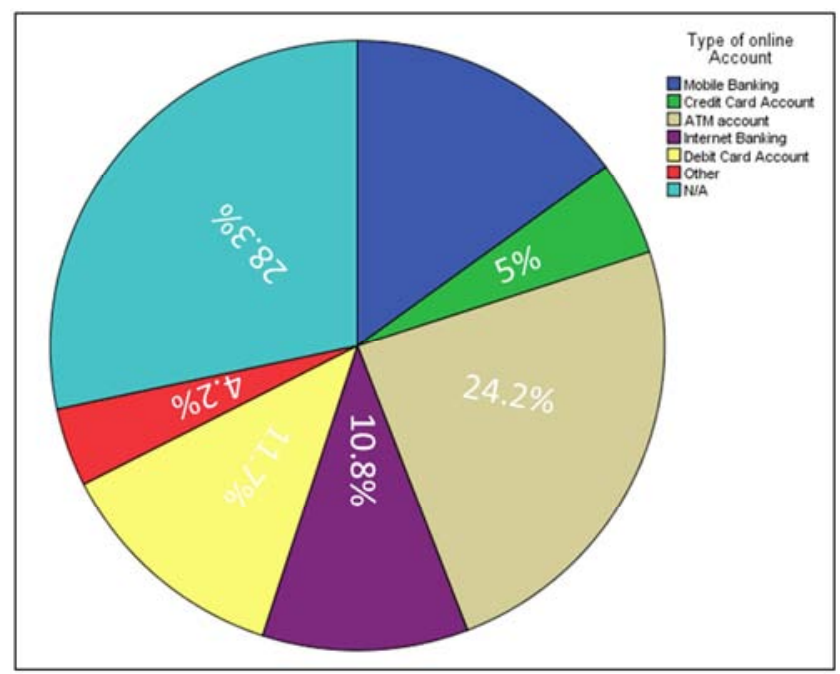

Figure 1. (Pie diagram showed the online account maintained by the respondents).

Figure 1 shows the percentage of respondents from uses various types of e-account. It also shows $28.3 \%$ respondents don't use any account, $15.8 \%$ uses mobile banking, 5\% respondents uses credit card account, e-account, 35.9\% (24.2\% respondents uses ATM card $+11.7 \%$ uses debit card ) uses ATM account, 10.8\% uses internet banking, $11.7 \%$ uses debit card account and $4.2 \%$ uses other accounts. 
Table 2. Type of Accounts and Educational Qualification of the Respondents.

\begin{tabular}{llllllll}
\hline \multirow{3}{*}{ Education } & \multicolumn{2}{l}{ Type of Online Account } & & & & Total \\
\cline { 2 - 7 } & $\begin{array}{l}\text { MobileBanking } \\
\text { No. (\%) }\end{array}$ & $\begin{array}{l}\text { Credit Card Account } \\
\text { No. (\%) }\end{array}$ & $\begin{array}{l}\text { ATM account } \\
\text { No. (\%) }\end{array}$ & $\begin{array}{l}\text { Internet Banking } \\
\text { No. (\%) }\end{array}$ & \multirow{2}{*}{ OtherNo. (\%) } & N/ANo. (\%) & \multirow{2}{*}{ No.(\%) } \\
\hline SSC & $0(0)$ & $0(0)$ & $2(50)$ & $0(0)$ & $0(0)$ & $2(50)$ & $4(3)$ \\
Bachelor Degree & $14(24)$ & $5(9)$ & $15(26)$ & $7(12)$ & $0(0)$ & $17(29)$ & $58(48)$ \\
Master Degree & $4(7)$ & $1(2)$ & $26(45)$ & $6(11)$ & $5(9)$ & $15(26)$ & $57(47)$ \\
Ph. D & 1 & 0 & 0 & 0 & 0 & 0 & $1(1)$ \\
Total & $19(16)$ & $6(5)$ & $43(35)$ & $13(11)$ & $5(4)$ & $34(28)$ & $120(100)$ \\
\hline
\end{tabular}

It is revealed from Table 2 that majority of the respondents (48\%) use online account are Bachelor Degree Holder. The next highest numbers of respondents use online accounts are
Master Degree Holder (47\%). Lowest number of respondents $(01 \%)$ is Ph.D. holders. Among the online accounts ATM account is used by majority (36\%) of the respondents.

Table 3. Security of ATM Booths and Location of the Respondents.

\begin{tabular}{lllllll}
\hline $\begin{array}{l}\text { Location of Respondents } \\
\text { No. (\%) }\end{array}$ & $\begin{array}{l}\text { Highly Secured } \\
\text { No. (\%) }\end{array}$ & $\begin{array}{l}\text { Sufficient Secured } \\
\text { No. (\%) }\end{array}$ & $\begin{array}{l}\text { Not enough } \\
\text { secured No. (\%) }\end{array}$ & $\begin{array}{l}\text { Not secured at all } \\
\text { No. (\%) }\end{array}$ & Don't know No. (\%) & $\begin{array}{l}\text { Total No. } \\
(\%)\end{array}$ \\
\hline Rural Area & $11(32)$ & $13(38)$ & $5(15)$ & $0(0)$ & $5(15)$ & $34(29)$ \\
Municipality & $3(7.5)$ & $16(40)$ & $17(42.5)$ & $1(2.5)$ & $3(7.5)$ & $40(33)$ \\
District town & $3(18)$ & $7(41)$ & $5(29)$ & $0(0)$ & $2(12)$ & $17(14)$ \\
City Corporation & $7(24)$ & $14(48)$ & $5(18)$ & $0(0)$ & $3(10)$ & $29(24)$ \\
Total & $24(15)$ & $50(42)$ & $38(31)$ & $1(80)$ & $13(11.2)$ & $120(100)$ \\
\hline
\end{tabular}

It is evident from Table 3 that among the respondents $29 \%$ from rural area, $33 \%$ from municipalities, $14 \%$ from various district town and $24 \%$ from different city corporations. $15 \%$ respondents from various locations mentioned that ATM account is highly secured and $31 \%$ respondents mentioned that security of ATM account is not sufficient in Bangladesh.
Out of the total respondents $11.2 \%$ do not know about the security status of ATM account in Bangladesh. Majority $(42.5 \%)$ users of municipal areas stated that security of ATM account is not enough and majority (48\%) users from city corporation mentioned that ATM account in Bangladesh is sufficient secured.

Table 4. Types of Online Account and E-Banking Security.

\begin{tabular}{|c|c|c|c|c|c|c|}
\hline Type of Online Account & $\begin{array}{l}\text { Highly Secured } \\
\text { No. }(\%)\end{array}$ & $\begin{array}{l}\text { Sufficient Secured } \\
\text { No. }(\%)\end{array}$ & $\begin{array}{l}\text { Not Enough } \\
\text { Secured No. (\%) }\end{array}$ & $\begin{array}{l}\text { Not Secured at all } \\
\text { No. }(\%)\end{array}$ & $\begin{array}{l}\text { Don't Know } \\
\text { No. }(\%) \\
\end{array}$ & Total No. (\%) \\
\hline Mobile Bank Account & $0(0)$ & $8(42.11)$ & $9(47.37)$ & $1(5.26)$ & $1(5.26)$ & $19(15.83)$ \\
\hline Credit Card Account & $4(66.67)$ & $2(33.33)$ & $0(0)$ & $0(0)$ & $0(0)$ & $6(5)$ \\
\hline ATM Account & $6(13.96)$ & $19(44.18)$ & $15(34.88)$ & $0(0)$ & $3(6.98)$ & $43(35.83)$ \\
\hline Internet Bank Account & $2(15.38)$ & $7(53.86)$ & $3(23.07)$ & $0(0)$ & $1(7.69)$ & $13(10.83)$ \\
\hline Other & $0(0)$ & $1(20)$ & $3(60)$ & $0(0)$ & $1(20)$ & $5(4.17)$ \\
\hline N/A & $6(17.65)$ & $13(38.23)$ & $8(23.53)$ & $0(0)$ & $7(20.59)$ & $34(28.34)$ \\
\hline Total & $18(15)$ & $50(41.67)$ & $38(31.67)$ & $1(83)$ & $13(10.83)$ & $120(100)$ \\
\hline
\end{tabular}

Table 4 shows that $15.83 \%$ respondents use mobile banking. Among the mobile bank account holders $42.11 \%$ feel that ebanking is sufficient secured. Among the ATM card users 06 said, this is not enough secured. Among the respondents $28.34 \%$ respondents don not have online account. Table shows that majority of the mobile bank account holders feel that security of this type of account is not enough. Credit card users feel this account is highly secured.

It is shown by Table 5 that e-banking in Bangladesh is not free from security problem of hijacker. Customers feel insecurity to withdraw money from ATM booths. In this research 49.1 percent respondents feel security problem from hijacker to withdraw and deposit money in ATM booths.

Table 5. Security Problem from Hijacker.

\begin{tabular}{llll}
\hline Security Problem & Frequency & Percent & Cumulative Percent \\
\hline Yes & 59 & 49.1 & 49.1 \\
No & 61 & 50.9 & 100 \\
Total & 120 & 100 & \\
\hline
\end{tabular}

Table 6. Internet Connection and Speed Quality of Internet Connection.

\begin{tabular}{lllllll}
\hline \multirow{2}{*}{$\begin{array}{l}\text { Name of Internet } \\
\text { Connection }\end{array}$} & \multicolumn{7}{l}{ Speed Quality of Internet Connection } & & & \\
\cline { 2 - 7 } & Excellent No. (\%) & Good No. (\%) & Slow No. (\%) & Very Slow No. (\%) & Not Applicable No. (\%) & Total No. (\%) \\
\hline Land Connection & $4(66.66)$ & $1(16.67)$ & $1(16.67)$ & $0(0)$ & $0(0)$ & $06(5)$ \\
GP Modem & $8(14.81)$ & $23(42.59)$ & $19(31.19)$ & $4(7.41)$ & $0(0)$ & $54(45)$ \\
Zoom Altra & $0(0)$ & $4(26.67)$ & $11(73.33)$ & $0(0)$ & $0(0)$ & $15(12.5)$ \\
WiMex Bangla Lion & $0(0)$ & $2(100)$ & $0(0)$ & $0(0)$ & $0(0)$ & $02(1.67)$ \\
\hline
\end{tabular}




\begin{tabular}{lllllll}
\hline \multirow{2}{*}{$\begin{array}{l}\text { Name of Internet } \\
\text { Connection }\end{array}$} & \multicolumn{6}{l}{ Speed Quality of Internet Connection } \\
\cline { 2 - 7 } & Excellent No. (\%) & Good No. (\%) & Slow No. (\%) & Very Slow No. (\%) & Not Applicable No. (\%) & Total No. (\%) \\
\hline Qubee & $0(0)$ & $2(100)$ & $0(0)$ & $0(0)$ & $0(0)$ & $02(1.67)$ \\
Robi & $0(0)$ & $0(0)$ & $1(100)$ & $0(0)$ & $0(0)$ & $01(83)$ \\
Other & $2(11.11)$ & $12(66.67)$ & $4(14.81)$ & $0(0)$ & $0(0)$ & $18(15)$ \\
No Connection & $0(0)$ & $0(0)$ & $0(0)$ & $0(0)$ & $22(100)$ & $22(18.33)$ \\
Total & $14(11.67)$ & $44(36.67)$ & $36(30)$ & $04(3.33)$ & $22(18.33)$ & $120(100)$ \\
\hline
\end{tabular}

It is obtained from Table 6 that majority of the respondents use GP Modem. Among the respondents $18.33 \%$ have no connection. All users of same connection don't feel same

comfort for the reason of location. Only 14 respondents feel the internet connection is excellent. Out of 120 respondents $30 \%$ users said the speed quality is slow and disturbing.

Table 7. Service Quality of ATM Accounts and ATM booths in Bangladesh.

\begin{tabular}{lllllll}
\hline \multirow{2}{*}{ Types of Bank } & \multicolumn{2}{l}{ E-Service Quality of Foreign Commercial Banks } & & \multicolumn{2}{c}{ Total } \\
\cline { 2 - 7 } & $\begin{array}{l}\text { Not Good } \\
\text { No. (\%) }\end{array}$ & $\begin{array}{l}\text { Satisfactory } \\
\text { No. (\%) }\end{array}$ & $\begin{array}{l}\text { Very Good } \\
\text { No. (\%) }\end{array}$ & $\begin{array}{l}\text { Excellent } \\
\text { No. (\%) }\end{array}$ & $\begin{array}{l}\text { Do not Know } \\
\text { No. (\%) }\end{array}$ & No. (\%) \\
\hline State Owned Commercial Banks & $12(30.77)$ & $10(25.64)$ & $7(17.95)$ & $9(23.07)$ & $1(2.56)$ & $39(32.5)$ \\
Domestic Private Commercial Banks & $4(6.15)$ & $13(20)$ & $27(41.54)$ & $20(30.77)$ & $1(1.54)$ & $65(54.17)$ \\
Foreign Commercial Banks & $2(12.5)$ & $1(6.25)$ & $6(37.5)$ & $7(43.75)$ & $0(0 \%)$ & $16(13.33)$ \\
Total & $8(6.67)$ & $25(20.83)$ & $46(38.33)$ & $39(32.5)$ & $2(1.67)$ & $120(100)$ \\
\hline
\end{tabular}

Table shows that majority of respondents (41.54\%) from domestic private commercial banks gave their opinion that ATM service quality of their bank is very good, and majority respondents from state owned commercial banks mentioned that ATM service of their banks are not good. Same service of foreign commercial banks are excellent. According to $43.75 \%$ respondents from foreign commercial banks, ATM service of their bank is excellent.

Table 8. Problems of ATM accounts in Bangladesh.

\begin{tabular}{lll}
\hline Name of Problem & Percentages of Respondents \\
\hline & Yes & No \\
\hline Power Crisis & $75(62.50 \%)$ & $45(37.5 \%)$ \\
Slow Internet & $43(35.83 \%)$ & $77(64.17 \%)$ \\
Hijacker & $58(48.33 \%)$ & $62(51.67 \%)$ \\
Hackers hidden Camera & $26(21.67 \%)$ & $94(78.33 \%)$ \\
Unavailability of CC Camera & $39(32.5 \%)$ & $81(67.5 \%)$ \\
Security problem & $33(27.5 \%)$ & $87(72.5 \%)$ \\
Unavailability of services for 24 hours access & $59(49.17 \%)$ & $61(50.83 \%)$ \\
Provision of Finger Print \& Digital Signature for Securing Account & $3428.33 \%$ & $8671.67 \%$ \\
\hline
\end{tabular}

It is gained from Table 8 that out of 120 respondents $62.50 \%$ mentioned that power crisis, $35.83 \%$ stated slow internet speed, $48.33 \%$ mentioned insecurity from hijacker to withdraw or deposit cash in ATM booths, 21.6\% said hackers hidden camera, $32.5 \%$ mentioned the unviability of close circuit camera inside and outside of ATM booths, $49.17 \%$ mentioned the unavailability of services for 24 hours, $28.33 \%$ users said there has no provision to use finger print $\&$ digital signature to make the account more secured and $27.5 \%$ users feel insecurity to use ATM booths in Bangladesh.

\section{Findings}

1. ATM location: All the ATM booths of Bangladeshi banks are not in safe position. It is investigated from the Table 03 that maximum ATM booths in municipal area is not in safe location and majority (48\%) ATM booths in City Corporation are in secured area.

2. Users of ATM account: All types of users are concerned about ATM account. It is revealed from Table 2 that majority of the respondents (48\%) use online account are Bachelor Degree Holder. The next highest numbers of respondents use online accounts are Master Degree Holder (47\%). Lowest number of respondents $(01 \%)$ is $\mathrm{Ph}$. D. holders. Among the online accounts ATM account is used by the majority (36\%) of respondents.

3. Insecurity from Hijacker: Customers feel insecurity from hijacker to withdraw and deposit money. Table 5 indicates that among the respondents $49 \%$ perceived insecurity from hijacker.

4. Slow Internet Speed: Quality of ATM services depends on speedy network. Almost all the banks are dependent on telecommunication companies for their internet connection. These companies are unable to provide high speed internet services to their clients. It is found from the Table No. 6 that among the respondents $30 \%$ mentioned the speed quality of internet connections is slow.

5. ATM Service Quality: ATM service quality in Bangladesh is very good. It is gained from table 7 that $38.33 \%$ respondents mentioned ATM service in Bangladesh are very good. Only $6.67 \%$ exposed that 
ATM service in Bangladesh is not good. Among the respondents of $41.54 \%$ from Domestic private commercial banks and $37.5 \%$ respondents from foreign commercial banks stated that in Bangladesh is very good.

6. Power Crisis: E-banking service is totally dependent on electricity. Till now total power production of Bangladesh is not enough to fulfill the total demand of the country. For this reason load shedding takes place almost in all the area on every day. Though every private commercial bank both foreign and domestic, has own generator to produce power for emergency period. But till now the state owned banks did not provide generator to each and every branches for emergency period. It is gained from Table 8 that among the respondents $62.50 \%$ mentioned that load shedding is one of the main a barrier for proper utilization and expansion of e-banking practices in Bangladesh.

7. Unavailability of ATM services for 24 hours: It is revealed from Table 8 that out of 120 respondents $49.17 \%$ mentioned that ATM services in Bangladesh are not available for 24 hours of a day.

8. Resisting Hacker's Hidden Camera: Hackers may set up any hidden-camera in side of ATM Booths to collect password of account holders. Then they will use this for hacking. It is gained from Table 8 that $21.67 \%$ users feel insecurity to use ATM booths for hackers' hidden camera. So ATM booths should be secured by resisting this camera to avoid this types of crime.

9. Use Finger Print and Digital Signature: Table 8 revealed that $28.33 \%$ users mentioned that their banks don't provide provisions to use finger print and digital signature to authenticate the actual user for avoiding hacking.

\section{Conclusion}

ATM account is one of the most popular e-banking services provided by the banks in Bangladesh. Almost all domestic private commercial banks and foreign commercial banks are offering this service to their customers. But the transactions in this system are not highly secured. In recent past many occurrence were happened by which users were suffered and the authorities didn't take any responsibility. So account holders feel insecurity to use ATM booths though some time they are bound to use ATM booths because of unavailability of cash in another sources. As Bangladeshi bank customers have limited knowledge on ebanking transactions. So they are not ready to accept any financial difficulties and further they will not trust on ebanking services it they will feel on any insecurities or any kind of difficulties. So bankers have to be sincere about ATM services and its security.

\section{References}

[1] Baten, M A and Kamil A A (2010) "E-Banking of Economical Prospects in Bangladesh." Journal of Internet Banking and Commerce. Vol. 15, No. 2.

[2] Hasan, A. H. M. S, Baten, M. A, Kamil, A. A. and Parvin, S. (2010) "Adoption of E-Banking in Bangladesh: An exploratory Study." African Journal of Business Management. Vol.4, No.13.

[3] Biswas, Shyamapada et.al. (2011). "Electronic Banking in Bangladesh: Security Issues, Forms, Opportunities and Challenges." Canadian Journal on Scientific and Industrial Research. Vol. 2 No. 5.

[4] Yas, Shilpan V. (2008) "Impact of E-Banking on Traditional Banking Services." School of Computer Science and Information Technology, Singhania University, Pacheri Bari, Jhunjhunu - 333515, Rajasthan, India.

[5] Kallol, Asif Showkat (2014) "Government to Allocate Tk.5, 000 Corers to Rescue Four Banks.” Dhaka Tribune.

[6] Sadekin \& Shaikh (2015) "Current Status of E-Banking Practices in Bangladesh" Scholar Journal for Business and Social Science, V-1, I-1.

[7] Rahman, M. (2003). Present Status of E-Banking in Bangladesh, Journal of the Institute of Bankers Bangladesh, 50 (1), 54-63.

[8] Ali, M. M., Ahmed, R. Rahman, A. and Azam, M. M. (2007). Electronic banking in Bangladesh: Potential and Constraints, Dhaka University Journal 1-19.

[9] Al-Amin, Shyeedul and Rahman, S Saifur (2010), "Application of Electronic Banking in Bangladesh: An Overview." Bangladesh Research Publication Journal. ISSN: 1998-2003, Volume-4, Issue: 2, Page 172-184.

[10] Islam, M M, (2005) "Proposed ICT Infrastructure for Ebanking in Bangladesh". Department of Computer and Systems Sciences, Royal Institute of Technology (KTH), Stockholm, Sweden. 